\title{
TRANSFERS OF INTRACELLULAR POTASSIUM IN EXPERIMENTAL DEHYDRATION ${ }^{1}$
}

\author{
By J. RUSSELL ELKINTON ${ }^{2}$ AND ALEXANDER W. WINKLER \\ (From the Department of Internal Medicine, Yale University School of Medicine, New Haven)
}

(Received for publication July 2, 1943)

Prolonged dehydration and starvation in the dog result in the sacrifice by the organism of more potassium than that derived from the breakdown of tissue (1). There is no comparable sacrifice of sodium. As a result, the diminution of intracellular fluid is exaggerated while that of extracellular fluid is minimized. The present experiments seek to define more generally the circumstances under which this loss of intracellular potassium may occur. This has been done by studying the transfers of potassium and of nitrogen associated with various alterations in the amount and distribution of water and of salts within the body.

\section{METHODS AND CALCULATIONS}

The methods of chemical analyses and of calculating the changes in the distribution of water and electrolytes have been described in detail elsewhere (1). The essential formulae used are reproduced here without rationale.

(a) Total water change, $\Delta \mathrm{W}$ :

In acute experiments, $\Delta \mathrm{W}_{\mathrm{I}}=\Delta \mathrm{Wt}^{\prime}$.

In chronic experiments (12 hours or longer),

$$
\Delta \mathrm{W}_{\mathrm{I}}=\Delta \mathrm{Wt}^{\prime}+0.49 \mathrm{P}+\frac{\text { Total calories }-4.1 \mathrm{P}}{9.3}
$$

where

$\Delta W_{I}=$ total water change in experiments where a metabolic calculation could be made,

$\Delta \mathrm{Wt}^{\prime}=$ the weight change corrected for solids lost,

$\mathbf{P}=$ the protein burned, obtained by multiplying the nitrogen balance, corrected for changes in NPN, by 6.25 ,

Total calories $=2$ per kilogram body weight per hour, decreasing 1.5 per cent per day.

In the chronic experiments where a metabolic calculation could not be made:

$$
\Delta \mathrm{W}_{\mathrm{II}}=\Delta \mathrm{E}_{\mathrm{Cl}}+\Delta \mathrm{I}_{\mathrm{II}}
$$

1 Aided by grants from the John and Mary R. Markle Foundation, the Ella Sachs Plotz Fund, and the Fluid Research Fund of Yale University.

2 National Research Council Fellow in the Medical Sciences, 1940-42. (b) Extracellular volume change, $\Delta \mathrm{E}$ :

$$
\Delta \mathrm{E}=\mathrm{E}_{\mathbf{2}}-\mathrm{E}_{1} \text {, }
$$

$E_{2}$ being calculated in two independent ways:

$$
\begin{aligned}
E_{\mathrm{Cl}_{2}} & =\frac{E_{1} \mathrm{Cl}_{1}+\mathrm{b}_{\mathrm{Cl}}}{\mathrm{Cl}_{2}}, \\
\mathrm{E}_{\mathrm{Na}_{2}} & =\frac{\mathrm{E}_{1} \mathrm{Na}_{1}+\mathrm{b}_{\mathrm{Na}}}{\mathrm{Na}_{2}},
\end{aligned}
$$

where

$$
\begin{aligned}
b_{C l} \text { and } b_{\mathrm{Na}}= & \text { balance of chloride and of sodium, re- } \\
\text { spectively. } & \begin{aligned}
\mathrm{E}_{1}= & \text { initial extracellular fluid = liters cor- } \\
& \text { responding to one-fourth of the body } \\
& \text { weight in kilograms. }
\end{aligned} \\
\mathrm{Cl}_{1} \text { and } \mathrm{Cl}_{2}= & \begin{array}{l}
\text { initial and final concentration of chlor- } \\
\text { ide in extracellular water. }
\end{array} \\
\mathrm{Na}_{1} \text { and } \mathrm{Na}_{2}= & \text { initial and final concentration of so- } \\
& \text { dium in extracellular water. }
\end{aligned}
$$

The concentrations of chloride, sodium, and potassium in extracellular water (ECW) were calculated from the serum concentrations (s) by the use of a Donnan factor of 0.95 :

$$
\begin{aligned}
\mathrm{Cl}_{\text {ECW }} & =\mathrm{Cl}_{\mathrm{s}} / \mathrm{W}_{\mathrm{s}} \times 0.95 \\
\mathrm{Na}_{\text {ECW }} & =\mathrm{Na}_{\mathrm{s}} \times 0.95 / \mathrm{W}_{\mathrm{s}} \\
\mathrm{K}_{\text {ECW }} & =\mathrm{K}_{\mathrm{s}} \times 0.95 / \mathrm{W}_{\mathrm{s}}
\end{aligned}
$$

Where $W_{\mathbf{s}}=$ grams of water in one ml. of serum. In the chronic experiments (Experiments 11C, 13A, and 14), $\mathrm{W}_{\mathrm{B}}$ was assumed equal to $0.93 \mathrm{grams}$ per ml. serum; in the acute experiments it was determined chemically.

(c) Intracellular volume change, $\Delta \mathrm{I}$ :

This was estimated in two independent ways.

$$
\begin{aligned}
\Delta \mathrm{I}_{\mathrm{I}} \text { (first method) } & =\Delta \mathrm{W}-\Delta \mathrm{E}_{\mathrm{Cl}}, \\
\Delta \mathrm{I}_{\mathrm{II}} \text { (second method) } & =2.7 \mathrm{P}
\end{aligned}
$$

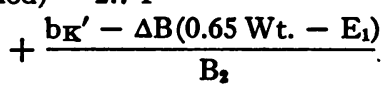

where

$$
\begin{aligned}
W_{t .}= & \text { initial body weight in kilograms, } \\
P= & \text { protein burned, in kilograms, } \\
b_{K}= & b_{K}-\left(K_{E C W_{2}} \times E_{2}\right)+\left(K_{E C W_{1}} \times E_{1}\right) \\
& -380 P=\text { balance of "excess" potas- } \\
& \text { sium, } \\
b_{K}= & \text { total balance of potassium, } \\
\Delta B= & B_{2}-B_{1}, \\
B= & N a{ }_{B C W}+10 \text { m.eq. per liter. }
\end{aligned}
$$


The term "balance" or the symbol " $b$ " indicates a retention by the organism when the sign is positive and a loss when the sign is negative. "Change" $(\Delta)$ likewise indicates a gain or loss according to the sign.

(d) Balance of "excess potassium," $\mathrm{b}_{\mathrm{K}}$ ':

The term "excess potassium" is used to designate potassium which moves in excess of nitrogen, i.e., potassium, leaving or entering the intracellular fluid, which is not associated with the catabolism or anabolism of protein. It is the sum of two elements, one already excreted in the urine and one which has moved into the extracellular fluid but has not yet been excreted, and is, therefore, a balance in relation to the cells rather than the organism. It is given by Equation 12. The factor by which $P$ is multiplied, 380, is based on the assumption that the normal $\mathrm{K}: \mathrm{N}$ ratio in dog muscle is $2.38 \mathrm{~m}$.eq. of potassium per gram of nitrogen. This represents the average ratio of potassium to nitrogen found in the intracellular phase of skeletal muscle of 20 normal dogs by Hastings (2), assuming 92.6 per cent of the solids to be protein (3).

This $\mathrm{K}: \mathrm{N}$ ratio is the lowest ratio in 6 series of analyses of skeletal muscle in dogs (2 to 7), the highest, 2.94, being that found by Eichelberger. Use of the lowest value results in somewhat higher values for "excess" potassium, but the difference is relatively slight. Had Eichelberger's ratio, rather than that of Hastings, been used in the control periods of the 3 balance experiments, the mean balance of "excess" potassium ( $\mathrm{b}_{\mathrm{k}}$ ') would have changed from -0.17 to $-\mathbf{0 . 1 3}$ m.eq. per kilogram body weight. This difference is statistically negligible, since the standard deviation of this mean was \pm 0.31 m.eq. per kilogram.

In a starving dog, allowed to drink water ad libitum (unpublished experiment), the ratio of the negative balance of potassium to that of nitrogen, from the sixth to the fourteenth day of the fast, was found to be 2.30. This should approximately represent the ratio of these substances in wasting tissue, and is in good agreement with the ratio of $\mathbf{2 . 3 8}$ derived from Hasting's muscle analyses.

\section{EXPERIMENTAL PROCEDURE}

Adult female dogs were used throughout. Net balances of water, chloride, potassium, and nitrogen were measured in all experiments. In the 3 chronic balance experiments (11C, 13A, and 14), dogs were fed a constant daily diet of "Maro" Meat Mixture for 8 to 13 days. One kilogram of this meat mixture contained by analysis: water, 736 grams; chloride, 117 m.eq.; potassium, 66.2 m.eq.; and nitrogen, 23.1 grams. In Experiment 11C, the daily intake of the meat mixture was 300 grams, in Experiment 14, 250 grams, and in Experiment 13A, 400 grams (except on the 5th day when the intake was 280 grams). Water ad libitum was supplied. Balances were determined for each daily period. On certain days, sodium chloride in hypertonic, isotonic, or hypotonic solution was given intravenously. The balances of total potassium, nitrogen, and of excess potassium on these days of saline injection were compared with mean control values. In computing the mean control values, all remaining daily periods were used, except the 2 daily periods following each period of significant "excess" potassium loss, subsequent to a saline injection; 14 periods in all were included.

The 13 acute experiments lasted from 2 to 24 hours. Sodium and chloride balances were followed in all of the experiments. Preliminary ureteral ligation, under dial anesthesia, was done in 4 experiments (15 to 18 ) in which 5 per cent sodium chloride was injected. Two of the animals (Experiments 15,16 ) received the injection intravenously, $2(17,18)$, intraperitoneally. Similar intraperitoneal injections of 5 per cent saline were given to 4 other dogs (Experiments 19, 20, 21, 11E) with intact kidneys, the first 3 under dial anesthesia and the last under morphine analgesia. In the 6 dogs receiving intraperitoneal injections (Experiments 17, 18, 19, 20, 21, 11E), a volume of peritoneal fluid, somewhat greater than that injected, was withdrawn 30 or $\mathbf{4 0}$ minutes after the initial injection. Since the concentration of salt in this fluid was always much less than 5 per cent, the final effect of the combined intraperitoneal injection and withdrawal was an increase in the salt content and a decrease in the water content of the body in all 6 experiments. In still another experiment (13C), a solution of 5 per cent glucose in 10 per cent urea was injected intraperitoneally, and 4 hours later an equal volume of peritoneal fluid was removed. This fluid now contained salt but had a lower urea concentration than did the original solution. The absorbed urea provoked a diuresis so that the procedure resulted in a water loss without hypertonicity of the body fluids, at least for the first 12 hours. In still another group of 4 experiments with diuresis, unanesthetized dogs were each given intravenously one of the following solutions: 5 per cent glucose in 10 per cent urea $(12 \mathrm{C}) ; 1.1$ per cent sodium sulfate in 10 per cent urea (13B); 5 per cent glucose alone (11D); and 1.1 per cent sodium sulfate alone (22A).

\section{RESULTS}

(a) Chronic balance experiments. The results of these 3 experiments are presented in Table $I$. The range of daily variations of total water $(\Delta \mathrm{W})$ did not exceed \pm 4 per cent. Serum potassium concentration was virtually unchanged from day to day. The mean balance of excess potassium, $b_{K^{\prime}}$, in 14 normal daily periods in the 3 dogs, equalled -0.17 m.eq. per kilogram of body weight. Changes in $b_{\mathbf{x}^{\prime}}$ in the periods of saline injection were considered significant only if they differed from this mean value by an amount exceeding twice the standard deviation, i.e., if they were greater than +0.45 or less than -0.79 m.eq. per kilogram.

The injection of hypertonic ( 5 per cent) sodium chloride solution regularly produced a significant negative balance of excess potassium. The 
TABLE I

Chronic experiments: analytical data, and calculations of balance of "excess" potassium and of changes in body fluid phases

\begin{tabular}{|c|c|c|c|c|c|c|c|c|c|c|c|c|c|c|}
\hline \multirow{2}{*}{$\begin{array}{c}\text { Experi- } \\
\text { ment }\end{array}$} & \multirow{2}{*}{$\begin{array}{c}\text { Intravenous } \\
\text { NaCl } \\
\text { solution } \\
\text { conc. amt. }\end{array}$} & \multirow{2}{*}{$\begin{array}{c}\text { Time } \\
\text { from } \\
\text { start of } \\
\text { experi- } \\
\text { ment }\end{array}$} & \multirow{2}{*}{$\begin{array}{c}\text { Body } \\
\text { weight }\end{array}$} & \multirow{2}{*}{$\begin{array}{l}\text { Blood } \\
\text { concen- } \\
\text { tration } \\
\text { NPN }\end{array}$} & \multicolumn{3}{|c|}{ Serum concentration } & \multicolumn{3}{|c|}{ Balance } & \multirow{2}{*}{$\mathbf{b}_{\mathbf{K}} \mathbf{n}^{*}$} & \multirow{2}{*}{$\Delta \mathbf{E}_{\mathrm{Cl}^{\dagger}}{ }^{\prime}$} & \multirow{2}{*}{$\Delta \mathbf{I}_{\mathbf{I I}} \ddagger$} & \multirow{2}{*}{$\Delta \mathbf{W}_{\mathbf{I I}}$} \\
\hline & & & & & $\mathbf{N a}$ & $\mathbf{C l}$ & $\mathbf{K}$ & $\mathrm{Cl}$ & $\mathbf{K}$ & $\mathbf{N}$ & & & & \\
\hline $11 \mathrm{C}$ & $\begin{array}{c}\text { per } \\
\text { cent cc. } \\
\text { None } \\
\text { Non } 500 \\
1.8 \quad 500 \\
\text { None } \\
\text { None } \\
5.0 \quad 300 \\
\text { None } \\
\text { None } \\
0.3500 \\
\text { None } \\
\text { None } \\
\text { None } \\
\text { None } \\
\text { None }\end{array}$ & $\begin{array}{c}\text { deys } \\
0 \\
1 \\
2 \\
3 \\
4 \\
5 \\
6 \\
7 \\
8 \\
9 \\
10 \\
11 \\
12 \\
13\end{array}$ & $\begin{array}{c}\mathrm{kgm} . \\
11.68 \\
11.72 \\
11.48 \\
11.58 \\
11.40 \\
10.98 \\
11.36 \\
11.36 \\
11.40 \\
11.34 \\
10.92 \\
10.78 \\
10.88 \\
10.84\end{array}$ & $\begin{array}{l}35 \\
35 \\
\\
46 \\
40 \\
30 \\
36 \\
37 \\
33\end{array}$ & 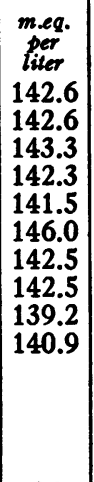 & 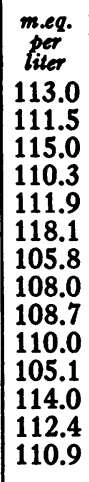 & 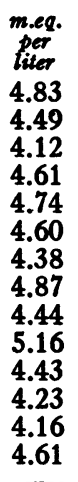 & $\begin{array}{r}+2.9 \\
+3.8 \\
+1.1 \\
-22.0 \\
+29.0 \\
-12.7 \\
+12.3 \\
+11.8 \\
-0.5 \\
-41.6 \\
-8.4 \\
+7.7 \\
+7.7\end{array}$ & $\begin{array}{r}-0.1 \\
-16.2 \\
+8.3 \\
-10.5 \\
-28.0 \\
+8.3 \\
+6.0 \\
-5.1 \\
-3.7 \\
-21.9 \\
-0.7 \\
+6.6 \\
+1.3\end{array}$ & $\begin{array}{l}-0.4 \\
-3.0 \\
+0.8 \\
-3.8 \\
-2.5 \\
-1.3 \\
-2.1 \\
-2.3 \\
-0.5 \\
-8.4 \\
-1.3 \\
+2.6 \\
+0.3\end{array}$ & $\begin{array}{c}\begin{array}{c}\text { m.eq. } \\
\text { per } \\
\mathrm{kgm} .\end{array} \\
+0.14 \\
+0.65 \\
+0.48 \\
+0.11 \\
-2.03 \\
+0.61 \\
+0.94 \\
+0.15 \\
-0.47 \\
+0.02 \\
+0.38 \\
+0.02 \\
-0.10\end{array}$ & $\begin{array}{l}+0.06 \\
-0.06 \\
+0.14 \\
-0.22 \\
+0.07 \\
+0.23 \\
+0.04 \\
+0.07 \\
-0.05 \\
-0.20 \\
-0.29 \\
+0.10 \\
+0.10\end{array}$ & $\begin{array}{l} \pm 0 \\
-0.10 \\
+0.07 \\
-0.07 \\
-0.31 \\
+0.13 \\
+0.03 \\
+0.10 \\
-0.10\end{array}$ & $\begin{array}{c}\text { liters } \\
\\
+0.06 \\
-0.16 \\
+0.21 \\
-0.29 \\
-0.24 \\
+0.36 \\
+0.07 \\
+0.17 \\
-0.15\end{array}$ \\
\hline $13 A$ & $\begin{array}{c}\text { None } \\
5.0 \quad 350 \\
\text { None } \\
\text { None } \\
0.9 \quad 500 \\
\text { None } \\
\text { None } \\
\text { None }\end{array}$ & $\begin{array}{l}0 \\
1 \\
2 \\
2 \\
3 \\
4 \\
5 \\
6 \\
7 \\
8\end{array}$ & $\begin{array}{l}11.66 \\
11.60 \\
10.64 \\
11.46 \\
11.50 \\
11.32 \\
11.28 \\
11.32 \\
11.30\end{array}$ & $\begin{array}{l}24 \\
23 \\
24 \\
25 \\
26 \\
24 \\
26 \\
23 \\
25 \\
24\end{array}$ & $\begin{array}{l}134.0 \\
136.5 \\
160.6 \\
147.5 \\
133.8 \\
145.0 \\
139.9 \\
143.5 \\
141.6 \\
139.9\end{array}$ & \begin{tabular}{|l}
108.1 \\
106.5 \\
130.2 \\
119.9 \\
109.5 \\
106.2 \\
106.9 \\
101.8 \\
106.3 \\
105.3
\end{tabular} & $\begin{array}{l}4.51 \\
4.74 \\
4.57 \\
4.27 \\
4.62 \\
3.93 \\
4.38 \\
3.60 \\
4.76 \\
4.25\end{array}$ & $\begin{array}{r}+0.1 \\
+57.4 \\
-64.6 \\
-11.0 \\
-26.4 \\
+7.4 \\
-2.1 \\
-8.5 \\
-\quad 1.5\end{array}$ & $\begin{array}{r}+9.2 \\
-31.2 \\
-4.0 \\
+8.7 \\
+11.5 \\
+4.2 \\
+9.3 \\
+7.0 \\
-0.5\end{array}$ & $\begin{array}{l}+4.8 \\
-3.9 \\
+3.5 \\
\pm 0 \\
+0.5 \\
+0.3 \\
+3.9 \\
+2.7 \\
+2.9\end{array}$ & $\begin{array}{l}-0.29 \\
-1.76 \\
-0.89 \\
+0.69 \\
+1.06 \\
-0.37 \\
+0.12 \\
-0.11 \\
-0.57\end{array}$ & $\begin{array}{l}+0.05 \\
-0.16 \\
-0.22 \\
+0.15 \\
-0.13 \\
+0.04 \\
+0.11 \\
+0.19 \\
+0.02\end{array}$ & $\begin{array}{l}-0.03 \\
-0.83 \\
+0.31 \\
+0.44 \\
-0.23 \\
+0.13 \\
-0.06 \\
+0.12 \\
+0.08\end{array}$ & $\begin{array}{l}+0.02 \\
-0.99 \\
+0.09 \\
+0.59 \\
-0.36 \\
+0.17 \\
+0.05 \\
-0.07 \\
+0.10\end{array}$ \\
\hline 14 & $\begin{array}{c}\text { None } \\
5.0 \quad 200 \\
\text { None } \\
\text { None } \\
0.9 \quad 350 \\
\text { None } \\
\text { None } \\
\text { None }\end{array}$ & $\begin{array}{l}0 \\
1 \\
2 \\
2 \| \\
3 \\
4 \\
5 \\
6 \\
7 \\
8\end{array}$ & $\begin{array}{l}7.36 \\
7.30 \\
\\
6.82 \\
7.82 \\
7.42 \\
7.40 \\
7.26 \\
7.28 \\
7.28\end{array}$ & $\begin{array}{l}30 \\
26 \\
25 \\
28 \\
28 \\
24 \\
30 \\
25 \\
22 \\
24\end{array}$ & $\begin{array}{l}138.8 \\
138.3 \\
153.8 \\
150.6 \\
138.3 \\
143.6 \\
141.7 \\
140.4 \\
144.6 \\
141.1\end{array}$ & $\begin{array}{l}108.7 \\
111.8 \\
120.7 \\
119.0 \\
109.2 \\
106.6 \\
106.6 \\
102.1 \\
109.3 \\
107.2\end{array}$ & $\begin{array}{l}4.89 \\
4.56 \\
4.55 \\
4.35 \\
3.60 \\
4.33 \\
4.35 \\
3.91 \\
4.70 \\
4.77\end{array}$ & $\begin{array}{r}-5.4 \\
+33.7 \\
+0.6 \\
+5.1 \\
+11.7 \\
+2.1 \\
-22.4 \\
+7.1 \\
+4.4\end{array}$ & $\begin{array}{r}-0.2 \\
-16.6 \\
+6.5 \\
+11.1 \\
+13.6 \\
+4.9 \\
+1.3 \\
+4.0 \\
+4.5\end{array}$ & $\begin{array}{l}-0.6 \\
-1.8 \\
+3.9 \\
\pm 0 \\
+4.2 \\
+2.5 \\
-0.7 \\
+1.5 \\
+1.4\end{array}$ & $\begin{array}{l}+0.24 \\
-1.77 \\
-0.30 \\
+1.73 \\
+0.12 \\
-0.05 \\
+0.18 \\
-0.17 \\
+0.15\end{array}$ & $\begin{array}{l}-0.09 \\
+0.12 \\
+0.03 \\
+0.20 \\
+0.16 \\
+0.01 \\
-0.09 \\
-0.08 \\
+0.07\end{array}$ & $\begin{array}{r}+0.02 \\
-0.39 \\
+0.10 \\
+0.31 \\
-0.04 \\
+0.08 \\
+0.02 \\
-0.06 \\
+0.11\end{array}$ & $\begin{array}{l}-0.07 \\
-0.27 \\
+0.13 \\
+0.51 \\
+0.12 \\
+0.09 \\
-0.07 \\
-0.14 \\
+0.18\end{array}$ \\
\hline
\end{tabular}

* $\mathrm{bK}^{\prime}$ = balance of "excess" potassium (see Equation 12 in METHODS AND CALculations), expressed as m.eq. per kilogram of initial body weight.

$\dagger \Delta E_{C l}=$ change in extracellular water volume (Equations 4,5 ).

$\ddagger \Delta I_{I I}=$ change in intracellular water volume (Equation 11).

$\Delta \mathrm{W}_{\mathrm{II}}=$ change in total water volume (Equation 3 ).

II Balances on the 2 nd day were determined at the end of 3 hours after the saline infusion and again at the end of 24 hours, and are given in that order.

In all tables time from start of experiment indicates end of period, at which time serum analyses were made and balances determined. Quantities are expressed per individual period rather than cumulatively. In designation of experiment, number refers to the individual dog; where a dog was used more than once, letter refers to successive experiments.

greater part of the excess potassium was excreted within the first 3 hours after the infusion (Experiments $13 \mathrm{~A}, 14)$. Isotonic ( 0.9 per cent) and hypotonic ( 0.3 per cent) solutions evoked no such response. The response to mildly hypertonic solutions (1.8 per cent) was equivocal. In the 48 hours following hypertonic injections, there was a marked decrease in the potassium excretion, so that $b_{\mathbf{x}^{\prime}}$ now became significantly posi- tive. This continued until a considerable part of that lost following the infusion had been restored.

(b) Acute experiments. The results of these experiments appear in Tables II and III. In the 4 dogs with ligated ureters (Experiments 15, 16, $17,18)$, the injection of hypertonic saline either intravenously or intraperitoneally was without significant effect on the potassium distribution. 
TABLE II

Acute experiments: exchanges of water, electrolytes, and nitrogen

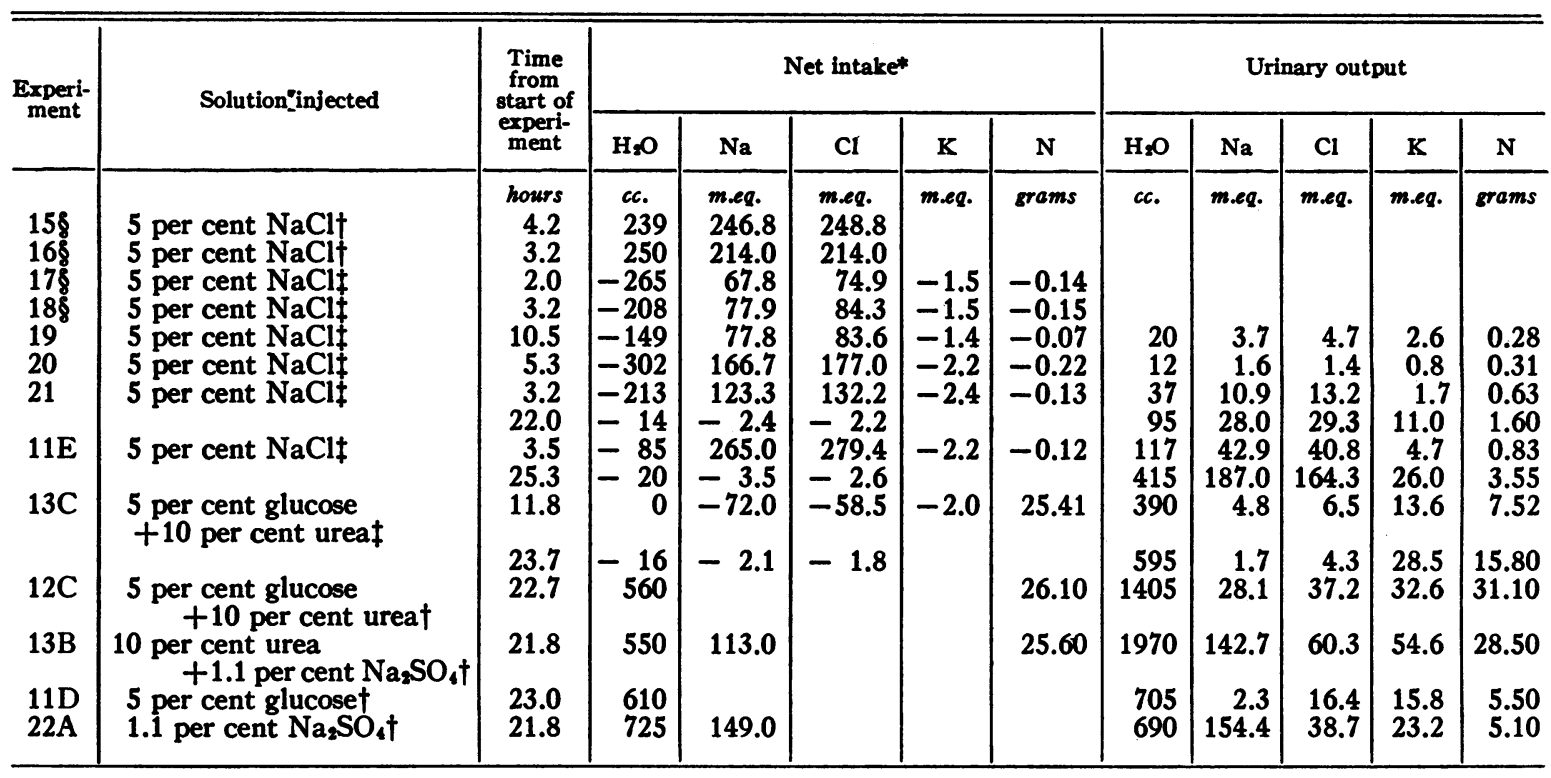

* Intake corrected for loss in serum specimen taken for analysis and peritoneal fluid withdrawn.

† Injected intravenously at start of experiment.

$¥$ Injected intraperitoneally at start of experiment.

$\$$ Ureters tied.

In 3 of the 4 dogs $(19,21,11 \mathrm{E})$ with intact kidneys, on the other hand, intraperitoneal injection of 5 per cent saline with subsequent withdrawal of fluid was followed by a significant loss of excess potassium in the urine. This negative balance developed only gradually (Experiment 21 ). This may account for the single exception (Experiment 20), since this dog died within 6 hours, before much urine had been passed. It was already very clear at the end of 11 hours (Experiment 19), and was still more evident after 24 hours. The loss of potassium was less rapid than that which followed intravenous injection of the same solution in the chronic balance experiments, and was associated with less acute diuresis. Concentration of potassium in serum rose slightly above the initial level in all but 1 experiment (Experiment 18), but, with the possible exception of Experiment 19, all the changes fell within the range of normal variation.

In Experiment 13C, a severe demand for water was coupled with a depletion of extracellular base. The result was a marked excretion of excess potassium even while the sodium concentration was depressed below normal. The serum potassium concentration rose slightly.
Of the last 4 experiments (12C, 13B, 11D, and 22A), the 2 dogs receiving the urea had a much more copious diuresis than did the control animals, and experienced a considerable net dehydration. The control pair merely excreted about enough urine to restore their water content to the initial value. The animals receiving the urea had a large excretion of excess potassium, while the other pair did not. Serum potassium rose slightly in one of the urea experiments but not in the other, while it decreased in the 2 control experiments.

\section{DISCUSSION}

The excretion of intracellular potassium in excess of that derived from the breakdown of tissue may occur in a variety of conditions involving alterations of the water or the salt content of the body. Benedict (8) and Gamble, Ross, and Tisdall (9) noted this phenomenon during the initial stages of starvation without water deprivation. Others have observed it in a variety of clinical conditions, such as diabetic coma (10), diarrhea of infants (11), hemorrhage (12), and water deprivation (13). It has been described in experiments with water deprivation in the rabbit (14). 
In man, it follows the ingestion of dry sodium chloride (15); in the dog, it follows the intravenous infusion of hypertonic sodium sulfate (16) and the injection of hypertonic saline in animals previously depleted of sodium and chloride (17).

Our experiments reported here and elsewhere $(1,18,19)$ give some negative and some positive clues to the factors common to all the diverse states in which there may be a loss of excess potassium. It cannot simply be the result of a temporary increase of plasma volume, since it is absent following intravenous injections of isotonic and hypotonic solutions (Table I, Experiments $11 \mathrm{C}, 13 \mathrm{~A}, 14)$ and since it appears as readily after intraperitoneal as after intravenous injections of hypertonic salt solutions (Tables II and III). It may occur with hypertonic sodium sulfate solution (16) and with concentrated urea solution (Tables II, III, Experiments 13C, 12C), as well as with hypertonic sodium chloride infusion (Table I), so that it is not a specific effect of some one salt. It occurs during dehydration without any additional salt being injected (1). Although usually associated with an increased concentration of electrolyte in the body, it may occur without any such increase (Experiment 13C).

In Figure 1, the balance of excess potassium, $b_{\mathbf{K}^{\prime}}$, is compared with the associated change in base concentration, $\Delta \mathrm{B}$, with the change in extracellular water, $\Delta \mathrm{E}$, with the change in intracellular water, $\Delta \mathrm{I}$, and with the change in total water,

TABLE III

Acute experiments: analytical data, and calculation of balance of "excess" potassium and of changes in body fluid phases

\begin{tabular}{|c|c|c|c|c|c|c|c|c|c|c|c|c|c|c|}
\hline \multirow{2}{*}{$\begin{array}{c}\text { Experi- } \\
\text { ment }\end{array}$} & \multirow{2}{*}{ Solution injected } & \multirow{2}{*}{$\begin{array}{c}\text { Time } \\
\text { from } \\
\text { start of } \\
\text { experi- } \\
\text { ment }\end{array}$} & \multirow{2}{*}{$\begin{array}{l}\text { Body** } \\
\text { weight }\end{array}$} & \multirow{2}{*}{$\begin{array}{l}\text { Blood } \\
\text { conc. } \\
\text { NPN }\end{array}$} & \multicolumn{4}{|c|}{ Serum concentration } & \multirow{2}{*}{$\mathbf{b}_{\mathbf{R}}$} & \multirow{2}{*}{$\Delta \mathbf{W}_{\mathbf{I}^{*}}$} & \multirow{2}{*}{$\Delta \mathbf{E}_{\mathbf{C I}}$} & \multirow{2}{*}{$\Delta \mathrm{E}_{\mathrm{Na}} \mathrm{N}_{1}$} & \multirow{2}{*}{$\Delta \mathbf{I}_{\mathbf{I}^{\#}}$} & \multirow{2}{*}{$\Delta \mathbf{I}_{\mathbf{I I}}$} \\
\hline & & & & & $\mathrm{H}_{2} \mathrm{O}$ & $\mathbf{N a}$ & $\mathbf{C l}$ & $\mathbf{K}$ & & & & & & \\
\hline $\begin{array}{c}168 \\
178 \\
188 \\
19 \\
20 \\
21\end{array}$ & 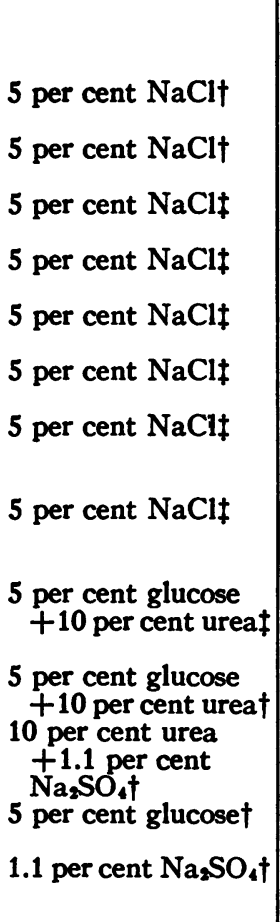 & $\begin{array}{c}\text { hours } \\
0 \\
4.2 \\
4.2 \\
0 \\
3.2 \\
0 \\
2.0 \\
0 \\
3.2 \\
0 \\
10.5 \\
0 \\
5.3 \\
0 \\
3.2 \\
22.0 \\
0 \\
3.5 \\
25.3 \\
0 \\
11.8 \\
23.7 \\
0 \\
22.7 \\
0 \\
21.8\end{array}$ & $\begin{array}{r}\mathrm{kgm} . \\
7.70 \\
\\
6.16 \\
6.30 \\
6.70 \\
6.38 \\
5.50 \\
5.22 \\
4.70 \\
9.35 \\
7.95 \\
7.58 \\
7.28 \\
12.22 \\
11.91 \\
11.23 \\
11.34 \\
10.64 \\
9.88 \\
12.90 \\
11.79 \\
11.56 \\
9.85\end{array}$ & $\begin{array}{r}\text { mgm. } \\
\text { per } \\
\text { cent } \\
50 \\
69 \\
50 \\
67 \\
47 \\
58 \\
51 \\
66 \\
34 \\
60 \\
46 \\
58 \\
42 \\
38 \\
27 \\
31 \\
31 \\
25 \\
32 \\
279 \\
126 \\
29 \\
46 \\
28 \\
34\end{array}$ & $\begin{array}{c}\text { grams } \\
\text { per } \\
\text { liter } \\
946 \\
962 \\
940 \\
957 \\
947 \\
952 \\
940 \\
941 \\
948 \\
950 \\
940 \\
941 \\
947 \\
946 \\
948 \\
942 \\
941 \\
937 \\
938 \\
919 \\
922 \\
936 \\
922 \\
947 \\
920\end{array}$ & $\begin{array}{c}\text { m.eq. } \\
\text { per } \\
\text { liter } \\
146.2 \\
192.0 \\
144.7 \\
183.2 \\
135.9 \\
164.0 \\
143.2 \\
165.9 \\
146.4 \\
171.6 \\
150.8 \\
181.2 \\
141.2 \\
173.3 \\
162.4 \\
139.5 \\
175.8 \\
156.5 \\
142.1 \\
130.3 \\
150.5 \\
143.8 \\
150.6 \\
145.8 \\
162.0\end{array}$ & $\begin{array}{c}\text { m.eq. } \\
\text { per } \\
\text { liter } \\
102.7 \\
167.3 \\
101.8 \\
161.6 \\
101.7 \\
134.5 \\
102.6 \\
143.1 \\
110.2 \\
145.2 \\
114.0 \\
160.6 \\
110.9 \\
155.5 \\
146.4 \\
107.2 \\
149.5 \\
130.2 \\
106.2 \\
92.6 \\
110.2 \\
104.4 \\
111.1 \\
101.6 \\
114.9\end{array}$ & $\begin{array}{l}\text { m.eq. } \\
\text { per } \\
\text { liter } \\
4.21 \\
4.38 \\
4.99 \\
5.75 \\
4.44 \\
4.96 \\
5.13 \\
4.74 \\
4.58 \\
6.14 \\
3.99 \\
5.11 \\
3.72 \\
3.75 \\
4.86 \\
4.03 \\
4.60 \\
4.44 \\
4.82 \\
5.88 \\
5.32 \\
3.76 \\
3.86 \\
4.16 \\
4.59\end{array}$ & $\begin{array}{c}\begin{array}{c}\text { m.eq. } \\
\text { per } \\
\text { kgm. } \\
-0.03 \\
-0.47 \\
-0.24 \\
+0.02 \\
-1.11 \\
-0.45 \\
-0.47 \\
-1.30 \\
-0.74 \\
-1.22 \\
-1.77 \\
-0.78 \\
-1.26 \\
-3.82\end{array} \\
\end{array}$ & $\begin{array}{l}+0.14 \\
-0.32 \\
-0.28 \\
\\
\\
-0.37 \\
-0.26 \\
-0.31 \\
-0.62 \\
-0.66 \\
-0.72 \\
-1.11 \\
-1.71\end{array}$ & $\begin{array}{l}+0.63 \\
+0.62 \\
+0.12 \\
+0.14 \\
+0.20 \\
+0.30 \\
+0.22 \\
-0.07 \\
+0.56 \\
-0.62 \\
-0.27 \\
-0.45 \\
-0.53 \\
-0.87 \\
-0.20 \\
-0.47\end{array}$ & $\begin{array}{l}+0.87 \\
+0.84 \\
+0.15 \\
+0.28 \\
+0.27 \\
+0.51 \\
+0.35 \\
-0.05 \\
+0.62 \\
-0.77 \\
-0.45 \\
-0.28 \\
-0.37 \\
-0.54 \\
+0.19 \\
-0.04\end{array}$ & $\begin{array}{l}-0.48 \\
-0.44 \\
-0.42 \\
\\
-0.59 \\
-0.19 \\
-0.87 \\
\pm 0 \\
-0.39 \\
-0.27 \\
-0.58 \\
-0.84 \\
+0.02 \\
-0.28\end{array}$ & $\begin{array}{l}-0.68 \\
-0.49 \\
-0.44 \\
-0.29 \\
-0.31 \\
-0.64 \\
-0.65 \\
+0.10 \\
-1.01 \\
+0.27 \\
+0.16 \\
-0.73 \\
-0.49 \\
-0.86 \\
+0.23 \\
-0.14\end{array}$ \\
\hline
\end{tabular}

8 ft See footnotes to Table II.

* $\mathrm{WI}_{\mathrm{I}}=$ change in total water volume (Equations 1,2 ).

$\| \Delta \mathrm{E}_{\mathrm{N}_{\mathrm{a}}}=$ change in extracellular water volume (Equations 4,6 ).

$\# \Delta \mathrm{I}_{\mathrm{I}}=$ change in intracellular water volume (Equation 10).

For other symbols see footnotes to Table I.

* Weights corrected for solids lost. 

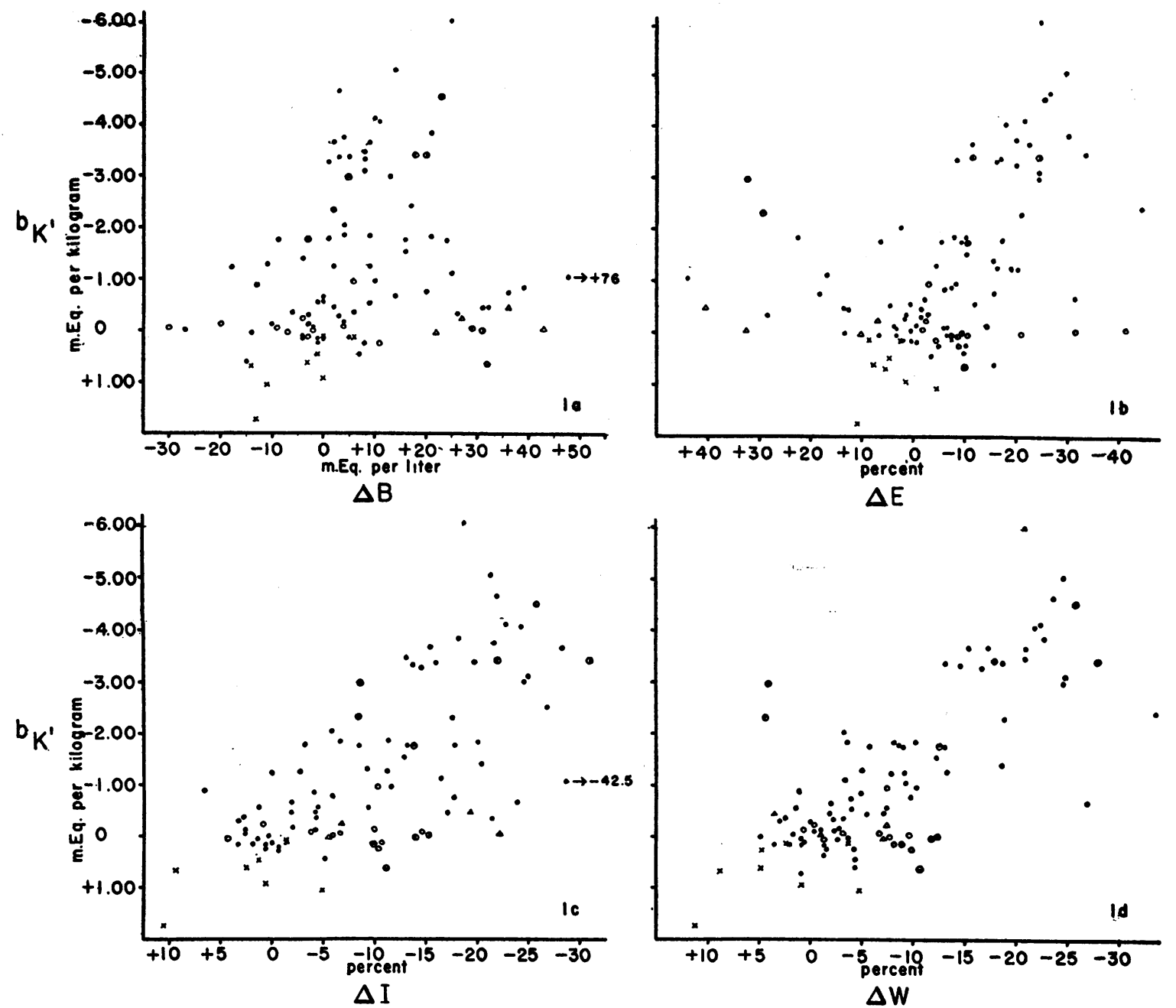

Fig. 1. Comparison of the Balance of "Excess" Potassium, br', with Changes in Tonicity of Body

Fluids, $\Delta \mathrm{B}(a)$; with Changes in Extracellular Flutd Volume, $\Delta \mathrm{E}$ (b); with Changes in Intracellular Fluid Volume, $\Delta \mathrm{I}(c)$; and with Changes in total Water Volume, $\Delta \mathrm{W}$ (d)

$b_{K}{ }^{\prime}$ is plotted along the ordinates in a negative direction, while $\Delta B, \Delta E, \Delta I$, and $\Delta W$, respectively, are plotted along the abscissae. Symbols represent balances determined under the following conditions: ureters tied, triangles; during 48 hours after significant losses of excess potassium in fed dogs, crosses; sodium chloride depletion, open circles; injection of hypertonic sodium chloride solution following sodium chloride depletion, circles containing dots; 2 successive periods during severe water depletion, divided circles; unspecified, solid black circles.

The data are from balances determined for 103 periods, in 24 different dogs, under 20 different experimental conditions producing alterations in water and salt contents of the body.

$\Delta \mathrm{W}$. Included are data from 103 different periods, in 24 different dogs, under 20 different experimental conditions, drawn from the experiments reported here and in other papers in our series $(1,18,19)$, as well as from unpublished data. There is obviously little significant correlation between $b_{K^{\prime}}$ and $\Delta \mathrm{B}$ or $\Delta \mathrm{E}$. There is a rough correlation between $b_{K}{ }^{\prime}$ and $\Delta I$, which is not surprising since loss of excess potassium from the cell necessarily favors a reduction in intracellular water. There may be an even better correlation between $b_{k}{ }^{\prime}$ and $\Delta W$. These two poor correlations and two good ones indicate that one feature, depletion of the body of water, is common to all these different procedures which result in the excretion of excess potassium. 
There are, however, certain important exceptions to the positive correlation between $b_{\mathbf{K}}{ }^{\prime}$ and $\Delta \mathrm{W}$ in Figure 1d. During periods of sodium chloride depletion, the loss of excess potassium was small in proportion to the severity of the water loss (open circles in lower right). When hypertonic saline was then injected following two such periods, there was a large loss of excess potassium in the presence of a positive balance of water (circles containing dots in upper left). These exceptions suggest that, while an elevated base concentration is not essential to the loss of excess potassium, it nevertheless favors this movement, while a low base concentration tends to inhibit it. It is also evident that, with continued dehydration, the loss of excess potassium tends to diminish. In the experiments in which balances were measured for two successive periods during water depletion, the loss of excess potassium was uniformly lower, in proportion to the water loss, in the second period than in the first (Figure 1d, divided circles).

Under some circumstances sodium may apparently enter cells in appreciable amounts. It is possible that sodium enters cells in exchange for the potassium which is lost, i.e., these transfers of potassium may merely represent an inter- change between intracellular and extracellular base. No water exchange would accompany such an exchange. The balance of excess intracellular sodium, $\mathbf{b N a}^{\prime}$, may be calculated in a manner exactly analogous to that by which the balance of excess potassium is calculated. The final formula is:

$$
\begin{aligned}
b_{N_{a}}{ }^{\prime}= & b_{\mathrm{Na}}-b_{\mathrm{NaP}_{\mathrm{P}}}-\mathrm{b}_{\mathrm{NaE}}=b_{\mathrm{Na}}-30 \\
& \times P-\left(\mathrm{NaECW}_{2} \times \mathrm{E}_{2}-\mathrm{NaECW}_{1} \times \mathrm{E}_{1}\right)
\end{aligned}
$$

These various symbols are defined elsewhere (1). In Figure 2, $b_{\mathbf{K}}{ }^{\prime}$ is plotted against $b_{\mathrm{Na}^{\prime}}{ }^{\prime}$, calculated in all experiments from which sufficient data are available. The poor correlation is evident. In certain cases, intracellular sodium and intracellular potassium do move in opposite directions, so that some measure of exchange does take place. However, these movements are too inconstant and unequal to provide any consistent explanation for the loss of excess potassium.

Great resistance of the concentration of serum potassium to change is apparent in our experiments. When the ureters were tied, there was no appreciable transfer of potassium to the extracellular fluid and no rise in serum concentrations. This is perhaps fortunate, as concentrations not much above normal are toxic (20). When the

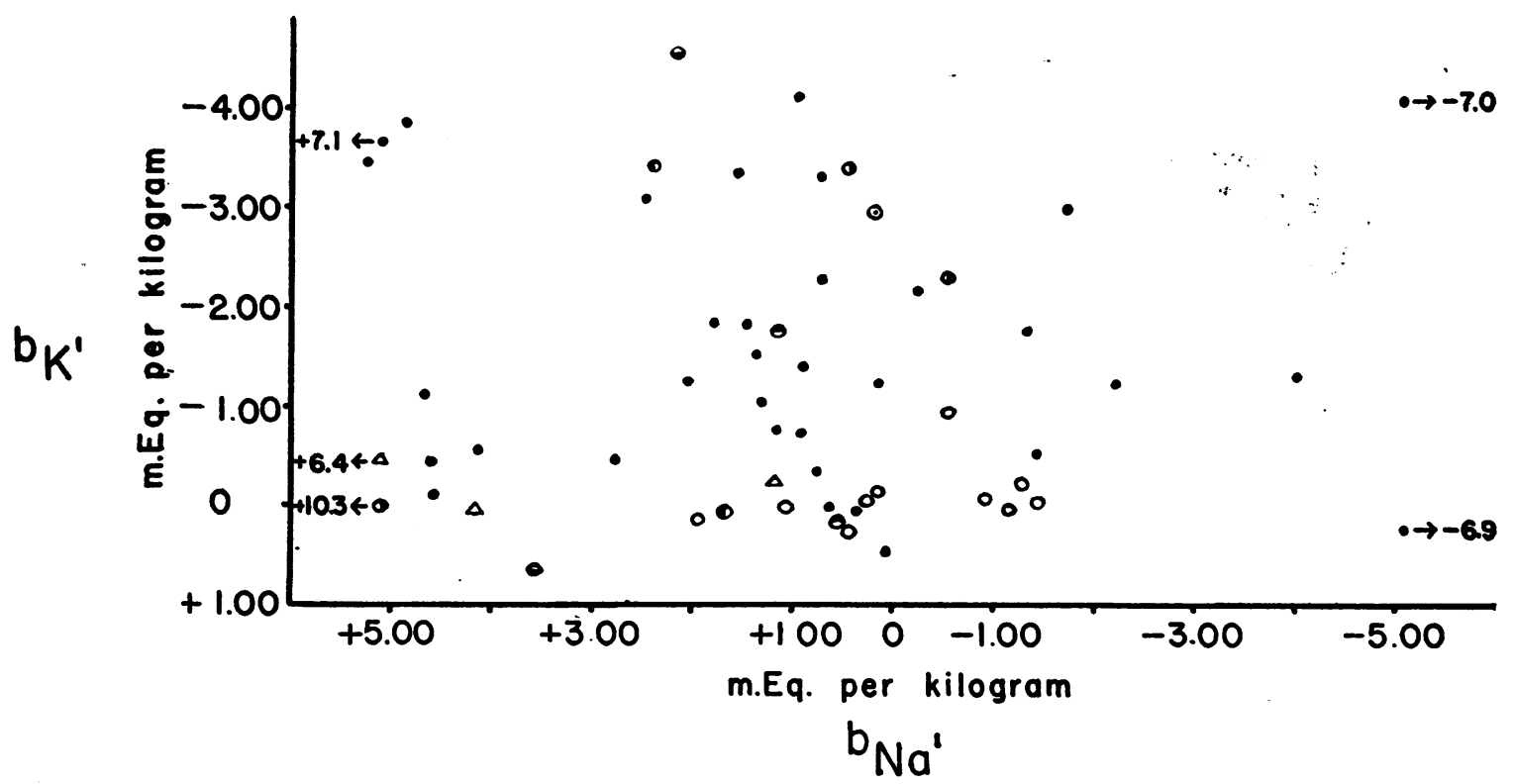

Fig. 2. Transfers of Intracellular Sodium ( $\mathrm{b}_{\mathrm{a}}{ }^{\prime}$ ) and Simultaneous Transfers of INTracellular Potassium ( $\left.b_{K}{ }^{\prime}\right)$

Symbols are as in Figure 1. There is little correlation. 


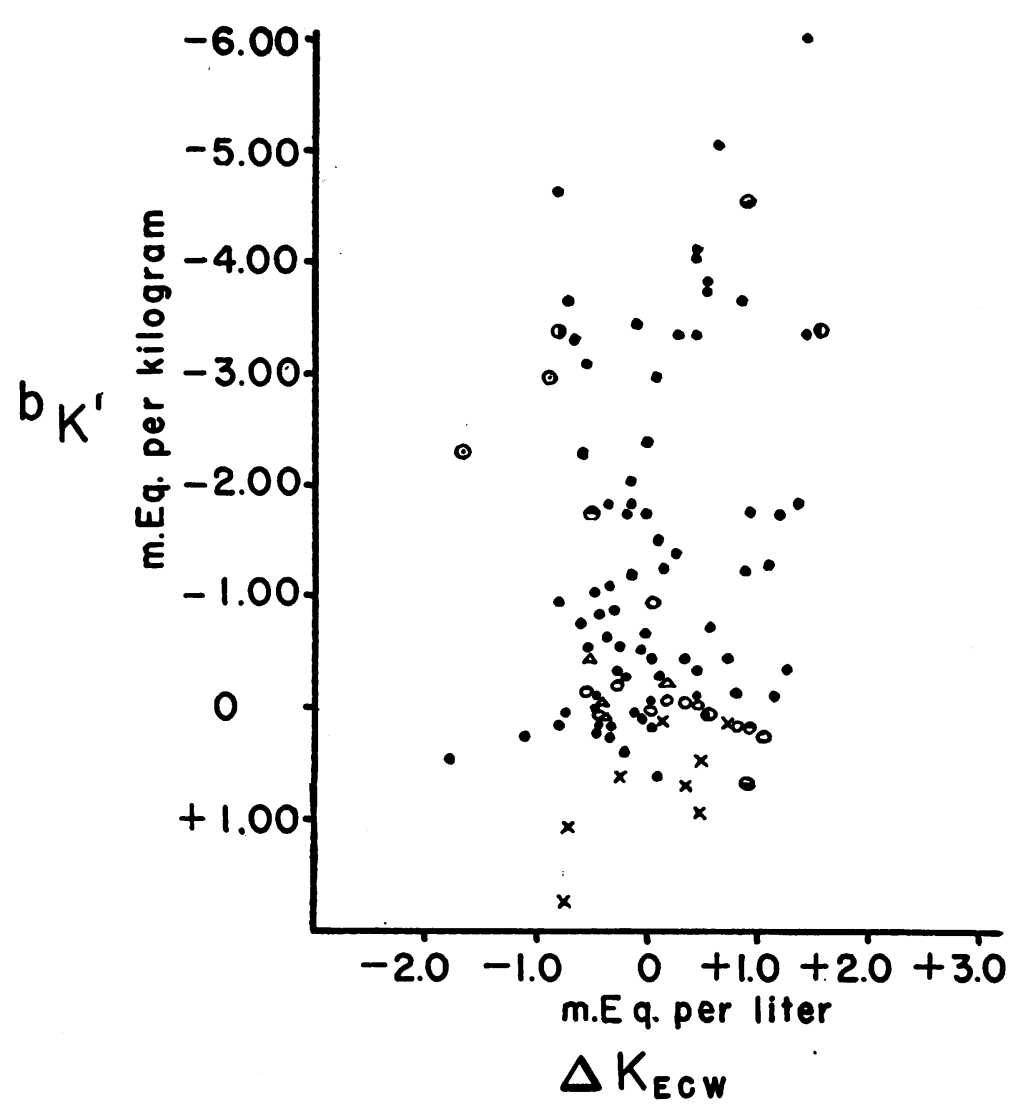

Fig. 3. Comparison of the Balance of "Excess" Potassium, br', with Changes in the Potassium Concentration in Extracellular WATER, $\triangle \mathrm{K}_{\mathrm{ECW}}$

br' $^{\prime}$ is plotted along the ordinate in a negative direction, while $\Delta \mathrm{K}_{\mathbf{E C W}}$ is plotted along the abscissa. Data are from the same periods as those in Figure 1. Symbols are as in Figure 1. Changes in serum potassium concentration associated with anoxia (blood drawn during heart block or after respirations had stopped) are omitted.

kidneys were intact, large amounts of excess potassium were removed from the cells without any consistent or large change in extracellular fluid concentration of potassium (Figure 3 ). This transfer may have involved alterations in the equilibrium between cellular and extracellular potassium, too small to be detected by present analytical methods. An entire series of reactions must be disturbed in the complex process of transferring potassium from tissue cells to urine. Our data do not clearly indicate which equilibrium is the first to be upset.

Large alterations in the cellular to extracellular potassium equilibrium apparently occur only where cell metabolism is affected, as in anoxia (21). Increases in the concentration of serum potassium, occurring in hemorrhage and intestinal obstruction, have been interpreted as replacements of lost extracellular by intracellular fluid (22 to 25). Such rises in concentration of serum potassium more probably reflect changes in cellular metabolism, since our experiments in uncomplicated water depletion indicate the marked stability of extracellular fluid concentration of potassium, even during extensive transfer and excretion of intracellular water and base.

There is much evidence that dehydration involving the loss of cellular water is less likely to provoke circulatory collapse than dehydration of the extracellular fluid alone $(17,26,19)$. Whatever the teleological interpretation, our experiments indicate that the release of potassium from 
the intact cell and its renal excretion is a general and reversible physiological response of the organism to severe depletion of water.

\section{CONCLUSIONS}

Loss of intracellular potassium in excess of that associated with protein catabolism is a general response to water depletion from any cause. Loss of intracellular water accompanies this loss of excess potassium, with the result that the loss of extracellular water is minimized. Renal activity is essential to effect this loss of potassium. Hypertonicity of the body fluids is a favorable but not an essential condition for this response.

The authors wish to thank Dr. Samuel Harvey for the use of the animal room of the Department of Surgery, and for the assistance of its staff.

\section{BIBLIOGRAPHY}

1. Elkinton, J. R., and Taffel, M., Prolonged water deprivation in the dog. J. Clin. Invest., 1942, 21, 787.

2. Hastings, A. B., and Eichelberger, L., The exchange of salt and water between muscle and blood. I. The effect of an increase in total body water produced by the intravenous injection of isotonic salt solutions. J. Biol. Chem., 1937, 117, 73.

3. Darrow, D. C., Harrison, H. E., and Taffel, M., Tissue electrolytes in adrenal insufficiency. J. Biol. Chem., 1939, 130, 487.

4. Muntwyler, E., Mellors, R. C., Mautz, F. R., and Mangun, G. H., Electrolyte and water equilibria in the dog. II. Electrolyte and water exchange between skeletal muscle and blood in adrenal insufficiency. J. Biol. Chem., 1940, 134, 367.

5. Eichelberger, L., The distribution of body water and electrolytes in skeletal muscle of dogs with experimental hydronephrosis following injections of potassium salts. J. Biol. Chem., 1941, 140, 467.

6. Ferrebee, J. W., et al., Certain effects of desoxycorticosterone. The development of "diabetes insipidus" and the replacement of muscle potassium by sodium in normal dogs. Am. J. Physiol., 1941, 135, 230.

7. Mellors, R. C., Muntwyler, E., and Mautz, F. R., Electrolyte and water exchange between skeletal muscle and plasma in the dog following acute and prolonged extracellular electrolyte loss. J. Biol. Chem., 1942, 144, 773.

8. Benedict, F. G., A study of prolonged fasting. Carnegie Institution of Washington, Washington, D. C., 1915.

9. Gamble, J. L., Ross, G. S., and Tisdall, F. F., The metabolism of fixed base during fasting. J. Biol. Chem., 1923, 57, 633.

10. Atchley, D. W., et al., On diabetic acidosis. A detailed study of electrolyte balances following the withdrawal and re-establishment of insulin therapy. J. Clin. Invest., 1933, 12, 297.

11. Butler, A. M., McKhann, C. F., and Gamble, J. L., Intracellular fluid loss in diarrheal disease. $\mathrm{J}$. Pediat., 1933, 3, 84.

12. Stewart, J. D., and Rourke, G. M., Intracellular fluid loss in hemorrhage. J. Clin. Invest., 1936, 15, 697.

13. Wiley, F. H., and Wiley, L. L., The inorganic salt balance during dehydration and recovery. J. Biol. Chem., 1933, 101, 83.

14. Kerpel-Fronius, E., Uber die beziehungen zwischen salz- und wasserhaushalt bei experimentellen wasserverlusten. Ztschr. f. Kinderh., 1935, 57, 489.

15. Gamble, J. L., Chemical anatomy, physiology, and pathology of extracellular fluid. A lecture syllabus. Department of Pediatrics, Harvard Medical School, Boston, Mass., 3rd Ed., 1941, Chart 34.

16. Schwartz, B. M., Smith, P. K., and Winkler, A. W., Renal excretion of sulfate. Am. J. Physiol., 1942, 137, 658.

17. Darrow, D. C., and Yannet, H., Metabolic studies of the changes in body electrolyte and distribution of body water induced experimentally by deficit of extracellular electrolyte. J. Clin. Invest., 1936, $15,419$.

18. Winkler, A. W., Elkinton, J. R., Hopper, J., Jr., and Hoff, H. E., Experimental hypertonicity: alterations in the distribution of body water, and the cause of death. J. Clin. Invest., 1944, 23, 103.

19. Hopper, J., Jr., Elkinton, J. R., and Winkler, A. W., Plasma volume of dogs in dehydration with and without salt loss. J. Clin. Invest., 1944, 23, 111.

20. Winkler, A. W., Hoff, H. E., and Smith, P. K., Electrocardiographic changes and concentration of potassium in serum following intravenous injection of potassium chloride. Am. J. Physiol., 1938, 124, 478.

21. Winkler, A. W., and Hoff, H. E., Potassium and the cause of death in traumatic shock. Am. J. Physiol., 1943, 139, 686.

22. Thaler, J. I., Evidence of permeability of tissue cells to potassium. Proc. Soc. Exper. Biol. and Med., 1935, 33, 368.

23. Fenn, W. O., The role of potassium in physiological processes. Physiol. Rev., 1940, $20,377$.

24. Lands, A. M., and Johnson, W., Distribution of body water following hemorrhage. Proc. Soc. Exper. Biol. and Med., 1942, 49, 123.

25. Scudder, J., and Zwemer, R. L., The effect of complete intestinal fistula on blood potassium. Surgery, 1937, 2, 519.

26. Nadal, J. W., Pedersen, S., and Maddock, W. G., A comparison between dehydration from salt loss and from water deprivation. J. Clin. Invest., 1941, 20, 691. 